INDONESIAN JOURNAL OF NURSING AND MIDWIFERY

\title{
Family Psychoeducation Increases the Role of Families in Caring for People with Mental Disorders
}

\author{
Desak Made Ari Dwi Jayanti, Ni Kadek Yuni Lestari
}

Sekolah Tinggi IImu Kesehatan Wira Medika Bali, Jalan Kecak No.9A, Tonja,

Kec. Denpasar Utara, Kota Denpasar, Bali

Email: djdesak@gmail.com

\section{Abstrak}

Psikoedukasi keluarga merupakan salah satu terapi keluarga yang mengabungkan intervensi klinis untuk dapat meningkatkan pemahaman keluarga sehingga meningkatkan kesehatan orang dengan gangguan jiwa. Tujuan penelitian ini adalah untuk mengetahui pengaruh psikoedukasi keluarga terhadap peran keluarga merawat orang dengan gangguan jiwa. Metode penelitian ini menggunakan design Quasi Eksperimen: pre-test dan post-test Control Group Design. Pengambilan sampel dengan purposive sampling. Sampel 20 orang kelompok kontrol dan 20 orang kelompok perlakuan. Uji Analisis mengunakan wilcoxon sign test (inter kelompok) dan Mann Whitney (antar kelompok). Hasil uji analisis inter kelompok pre dan post test pada kelompok kontrol $p$ value $=0,517$ yang artinya tidak ada perbedaan dan pada kelompok perlakuan $p$ value $=0,004$ yang artinya ada perbedaan. Uji analisis antar kelompok perlakuan dan kontol diperoleh $p$ value $=0,008$ yang artinya ada pengaruh psikoedukasi keluarga terhadap peran keluarga merawat orang dengan gangguan jiwa psikoedukasi keluarga dapat diterapkan pada keluarga dengan ODGJ.

Kata kunci: psikoedukasi keluarga; peran keluarga; ganggan jiwa

\begin{abstract}
Family psychoeducation is a family therapy that combines clinical interventions to increase family understanding in order to improve the health of people with mental disorders. The purpose of this study was to determine the effect of family psychoeducation on the role of the family caring for people with mental disorders. This study used a Quasi Experiment design: pre-test and post-test Control Group Design. The sample was taken by using purposive sampling. The sample was 20 people in the control group and 20 people in the treatment group. The analysis test used was the Wilcoxon sign test (intra-group) and the Mann Whitney (inter-group) test. The intra-group analysis test in the pre and post-test for the control group obtained $p$ value $=0.517$ which means there is no difference, while the treatment group obtained $p$ value $=0.004$ which means there is a difference. Inter-group analysis test of the treatment group and the control group obtained $p$ value $=0.008$, which means that there is an effect of family psychoeducation on the role of families in caring for people with mental disorders. Family psychoeducation can be applied to families with mentally disorders people.
\end{abstract}

Keywords : family psychoeducation, family caring, mental disorders

Article info:

Article submitted on November 02, 2020

Articles revised on December 04, 2020

Articles received on December 31, 2020

DOI: http://dx.doi.org/10.21927/jnki.2020.8(4).315-321 


\section{INTRODUCTION}

Mental disorders are a common problem. According to WHO (2016), 21 million people had schizophrenia and more than $50 \%$ did not get proper care (1). The data from Basic Health Research (2018) showed that in Indonesia, family members with schizophrenia mental disorders had increased. The data in 2013 was 1.7 permil and in 2018 was 7 permil. Bali, which initially ranked third then became first with data in 2013 was 2.3 permil and in 2018 was 11 permil (2). Denpasar city service data (2018) showed the incidence of schizophrenia mental disorders totaling 364 people, where the highest number was in the working area of Puskesmas II East Denpasar, totaling 108 people (3). The treatment for people with mental disorders requires a large budget that could be a burden to the family and society (4). People with mental disorders will also be unproductive and become a stigma for the family. Another consequence for people with mental disorders is experiencing shackling by their families. According to data from Riskesdas (2018), in the last three months there were 31.5\% of people with mental disorders who experienced shackling in Indonesia (2). The role of the family is needed in curing people with mental disorders because it is not enough to go to health services. The family's unpreparedness in caring for people with mental disorders is the cause of their recurrence.

It is evidenced by a number of $54.9 \%$ of families showing bad attitudes and $60.8 \%$ showing bad behavior (5). One of the efforts that can be given to improve the health of people with mental disorders and to increase family knowledge is by providing family psychoeducation (6). Family psychoeducation is a psychosocial therapy which is a combination of clinical action with family (7). Through family psychoeducation, family's welfare will be increased and the family's subjective burden can be lowered. The implementation of family psychoeducation is effective if it is carried out for 5 meetings consist of 5 sessions where it takes 45 minutes per session (8). Other studies have shown that family psychoeducation can increase family support and patient compliance in taking medication (9). Family psychoeducation can also reduce anxiety and the perception of family burdens in caring for children with mental retardation (10). The increasing number of mental disorders in Bali is due to recurrence. Because of the important role of the family in healing patients and preventing relapse, it is necessary to conduct research on the effect of family psychoeducation on the families' ability in caring for people with mental disorders.

\section{MATERIALS AND METHODS}

The research design used was a Quasi Experiment: pre-test and post-test Control Group Design which was carried out in the work area of the UPTD Puskesmas II of the East Denpasar District Health Office with a population of 108 people (3). The sample was determined by purposive sampling on families who have family members with mental disorders as many as 40 people with the division of 20 people in the control group and 20 people in the treatment group. The measuring instrument used was a questionnaire on the family's ability in caring for people with mental disorders (ODGJ) which had been tested for validity using Pearson Product Moment with a test result of 0.514 which means valid and the reliability test using Alpha Cronbac with a test result of 0.998 which means reliable (11). The categorical data scale was ordinal, so that the analysis test used for pre-test and post-test data between the control and treatment groups was the Wilcoxon sign test, while the inter-group analysis test used was the Mann Whitney.

Intervention within family psychoeducation was carried out for 5 sessions, each session lasting 45 minutes. Topics given in Session 1: Identifying changes that occur in people with mental disorders and problems that arise due 
to changes in people with mental disorders experienced by their families, Session 2: Exercise patient care by family, Session 3: Family stress management exercises, Session 4: Family Weight Management Exercises, Session 5: Community empowerment (Support system) helping families (8). Previous research with family psychoeducation showed an increase in family support and medication adherence (9).

\section{RESULTS AND DISCUSSION}

Table 1. Age

\begin{tabular}{lcccc}
\hline \multicolumn{1}{c}{ Group } & Mean & Median & Minimum & Maximum \\
\hline Treatment & 46.60 & 48.00 & 28 & 60 \\
Control & 45.95 & 45.00 & 37 & 58 \\
\hline
\end{tabular}

Table 2. Education

\begin{tabular}{lcccc}
\hline \multirow{2}{*}{ Education } & \multicolumn{2}{c}{ Treatment } & \multicolumn{2}{c}{ Control } \\
\cline { 2 - 5 } & $\mathbf{f}$ & $\mathbf{\%}$ & $\mathbf{f}$ & $\%$ \\
\hline Elementary & 3 & 15.0 & 1 & 5.0 \\
Junior High & 2 & 10.0 & 3 & 15.0 \\
Senior High & 14 & 70.0 & 15 & 75.0 \\
Uneducated & 1 & 5.0 & 1 & 5.0 \\
Total & 20 & 100.0 & 20 & 100.0 \\
\hline
\end{tabular}

Table 3 shows the $p$ value $=0.157$, which means there is no difference in the control group, while the $p$ value $=0.004$ shows that there is a difference in the pre-test and post-test data in the treatment group.

Table 3. Analysis of Intra-group Differences in PreTest and Post-Test on Control and Treatment Groups

\begin{tabular}{ccc}
\hline Group & $\mathbf{Z}$ & $\boldsymbol{p}$-value \\
\hline Control & $-1.414^{\mathrm{b}}$ & 0.157 \\
Treatment & $-2.887^{\mathrm{b}}$ & 0.004 \\
\hline
\end{tabular}

Data in Table 4 shows $p$ value $=0.671$ which means there is no difference in the pre-test analysis of the Treatment and Control Groups, while the $p$ value of 0.008 shows that there is a significant difference indicating that there is an effect of family psychoeducation on the role of the family in caring for people with mental disorders.
Table 4. Analysis of inter-group differences between the control and treatment groups

\begin{tabular}{cccc}
\hline \multicolumn{2}{c}{ Group Variable } & $\mathbf{n}$ & $\boldsymbol{p}$-value \\
\hline \multirow{2}{*}{ Family's role } & Pre-test & 20 & 0,671 \\
& Post-test & 20 & 0.008 \\
\hline
\end{tabular}

\section{Discussion}

Intra-group data analysis using the Wilcoxon Sign Test showed that there was no difference in the pre-test and post-test data in the Control Group with $p$ value: 0.157 (> 0.05) and there were differences in pre-test and post-test data on the role of the family in caring for people with mental disorders in the treatment group with $p$ value: $0.004(<0.05)$. Analysis of the differences between the control group and the treatment group using the Mann Whitney test showed that the $p$ value $=0.008(<0.05)$ means that there was an effect of family psychoeducation on the role of the family in caring for people with mental disorders. The role of the family is very important for the patient's recovery, therefore every therapy that the patient receives requires a family role in its implementation, one of which is family psychoeducation which is part of psychotherapy (6). Baroroh (2012) stated that a family who performs the role well will have a good impact on other family members because the they feel happy and like to get attention so that it can improve health (12). Farkah (2017) stated that giving good treatment will increase hope and a sense of optimism which will certainly improve the patient's recovery, while bad and insulting words will certainly worsen health. The role of the family as a caregiver will be a very important role in the health of patients (13). The study by Komalah (2016) showed that there was a significant reduction in families anxiety in caring for diabetes mellitus ulcer patients after being given family psychoeducation with a $p$ value of $0.000<\alpha(0.05)(14)$.

According to Stuart (2016), the goals of family psychoeducation are achieved through 
a comprehensive program consisting of an educational component, a skills component (communication, conflict resolution, problem solving, assertiveness, behavior management and stress management), an emotional component, and a social component, which are expected to improve family behavior and cognitive abilities so as to increase the role of the family, among others, in providing family support such as emotional support, social, physical, medication monitoring, and relapse prevention efforts. The most important thing from a family psychoeducation program is meeting the families' basic needs and giving families the opportunity to ask questions, exchange views and socialize with other members (15). The results of other study indicated that there was an effect of giving family psychoeducation on reducing family burdens and there was an increase in family support for families who had family members with schizophrenia (16). The results of other study showed that there was an increase in the mean behavior in caring for schizophrenic patients with hallucinations as many as 17.60 after being given family psychoeducation, with $\mathrm{t}$ value $=11,365$ and $p$ value $=0,000$ which indicated that there was an effect of family psychoeducation (17). Rahayu and Mubin's research results (2019) showed an increase in medication adherence after being given family psychoeducation (18).

The result of the study by Ahmad et al., (2019) showed an increase in family cognitive abilities after being given family psychoeducation (19). Sasono and Rohmi (2017) also stated that family psychoeducation increased the family's ability in caring people with schizophrenia which was indicated by an increase in cognitive, affective and family psycho-motor abilities (20). The results of other studies showed that psychoeducation could reduce anxiety and depression in families with autistic children with a value of $p=0.000$ (21). In addition, the research by Wulandari et al. (2017) found that there was an effect of family psychoeducation on reducing family burdens and increasing selfesteem in families who had children with mental retardation, this was evidenced by an analysis test that obtained $p=0.000$ (22).

Researchers argue that the increase in the role of the family after being given psychoeducation is because psychoeducation, which is consisting of several sessions, is able to increase knowledge, family skills in caring for patients, and the family emotional expressions response in caring so that patient recurrence can be minimized. The family psychoeducation provided will be able to increase knowledge and train psychomotor directly so that this therapy can be given to families who care for patients at home or be carried out by health workers during home visits and/or carried out separately for psychoeducation programs in order to form a family support group. Characteristics of the study sample in terms of age showed that the mean age in the control group was 45.96 years and in the treatment group was 46.60 years. This data showed that the respondents were in adulthood who were of productive age and had independence in caring for people with mental disorders, so giving family psychoeducation will further increase the ability and independence in caring for people with mental disorders. This opinion was supported by Friedman et al., (2010) who stated that independence is a behavior that does not depend on others and tries to solve his own problems and is responsible for what he does (23). The characteristics of respondents based on education showed that in both groups, most of respondents were in high school education, where each group shows $75 \%$ (Control Group) and $70 \%$ (Treatment Group). This showed that the two groups had the same educational characteristics and there were no significant gaps. The higher the level of education, the higher the knowledge, so that they will be easier to absorb information and the behavior will 
also be better. This opinion was supported by research conducted by Purwaningrum et all., (2018) who stated that there is a relationship between education and knowledge towards behavior(24).

\section{CONCLUSION AND RECOMMENDATION}

The results of the inter-group analysis showed that there was no difference in the control group with $p$ value $=0.157$, while the treatment group showed a difference with a $p$ value $=0.004$. The results of the inter-group analysis showed that there was an effect of family psychoeducation on the role of the family in caring for people with mental disorders with a $p$ value $=0.008$. It is recommended that families continue to carry out the information obtained after receiving psycho-educational therapy, such as: 1) always identifying problems that arise in family members who experience mental disorders and problems that result in the family; 2) caring for family members according to problems that arise and are scheduled; 3 ) doing stress management exercises by inhaling in and five finger relaxation techniques; 4) do family load management both subjectively and objectively by identifying feelings of sadness, loss, worry and anxiety as well as feelings of pressure, limited time, energy, finances, socialization and stigma, and the family can exploit the existing support system, thus the health of people with mental disorders will improve both physically and mentally. It is recommended that Puskesmas apply family psychoeducation therapy to all families who have people with mental disorders so that the role of the family can be increased.

\section{REFERENCES}

1. WHO. 2016. Hari Kesehatan Jiwa Sedunia. Available : www.idionline.org (30 Januari 2018).

2. Riset Kesehatan Dasar (Riskesdas) 2018. Kementerian Kesehatan Badan Penelitian
Dan Pengembangan Kesehatan RI 2018, diakses tanggal 5 Agustus $2018 \mathrm{http}: / /$ www.depkes.go.id/resources/download/ info-terkini/materi_rakorpop_2018/Hasil\%20 Riskesdas\%202018.pdf

3. Dinas Kota Denpasar. 2018. Laporan Data ODGJ Tahun 2018 Dinas Kesehatan Kabupaten/ Kota Denpasar

4. Riset Kesehatan Dasar (Riskesdas). 2013. Badan Penelitian dan Pengembangan Kesehatan Kementerian RI tahun 2013. Diakses: 5 Agustus 2018, dari http://www. depkes.go.id/resources/download/general/ Hasil\%20Riskesdas\%20 2013.pdf.

5. Rasmun. Sukamto, E. Piyanti, L. 2013. Faktor-Faktor Penyebab Kekambuhan Pada Pasien Skizofrenia. Jurnal Husada Mahakam Volume III No. 5, Mei 2013, hal. 200 - 262. diakses tanggal 8 agustus 2019.

6. Hawari, D. 2012. Pendekatan Holistik Pada Gangguan Jiwa : Skizofrenia, edisi 3. Jakarta : Badan Penerbit Fakultas Kedokteran Universitas Indonesia.

7. Suhron, Muhammad. 2017. Asuhan Keperawatan Jiwa Konsep Self Esteem. Jakarta : Mitra Wacana Media.

8. Wiyati,R. Wahyuningsih, D. Widayanti, E.D. 2010. Pengaruh Psikoedukasi Keluarga Terhadap Kemampuan Keluarga Dalam Merawat Klien Isolasi Sosial. Jurnal Keperawatan Soedirman (The Soedirman Journal of Nursing), Volume 5, No.2, Juli 2010 : 85-94. diakses tanggal 6 agustus 2019. http://jks.fikes.unsoed.ac.id/index.php/ jks/article/view/275/150

9. Sulastri dan Kartika. 2016. Psikoedukasi Keluarga Meningkatkan Kepatuhan Minum Obat ODGJ Di Puskesmas Kedaton Bandar Lampung. Jurnal Kesehatan, Volume VII, Nomor 2, Agustus 2016, Lampung : 323-328.

10. Rosmaharani, S. Wihastutu, T.A. Supriati, L. 2015. Pengaruh Psikoedukasi Keluarga Terhadap Perubahan Tingkat Kecemasan 
Dan Persepsi Beban Keluarga Merawat Anak Dengan Retardasi Mentaldi Sdlb Negeri Kabupaten Jombang. The Indonesian Journal of Health Science, vol. 5, no. 2, juni 2015. Diakses tanggal 7 Agustus 2019.

11. Ekawati,N.L.P. 2018. Pengaruh Psikoedukasi Keluarga Terhadap Peran Keluarga Sebagai Caregiver Pada Pasien Skizofrenia Di Poliklinik Jiwa Rsj Provinsi Bali Tahun 2018. Skripsi. STIKes Wira Medika Bali

12. Baroroh, D.B. 2012. Peran Keluarga Sebagai Caregiver Terhadap Pengelolaan Aktifitas Pada Lansia Dengan Pendekatan NIC (Nursing Intervention Classification) Dan NOC (Nursing Outcome Classification). Jurnal Keperawatan, ISSN 2086-3071 : 141-151.

13. Farkhah, Laeli. 2017. Faktor Caregiver dan Kekambuhan Klien Skizofrenia. JKP-Volume 5 Nomor 1 April 2017: 37-46. Diakses tanggal 21 September 2020.

14. Komalah, A.D. 2016. Efektivitas Psikoedukasi Keluarga Pada Caregiver Pasien Ulkus Diabetes Melitus Dalam Menurunkan Tingkat Ansietas. Jurnal Ilmu Keperawatan, Volume 4, No.2, November 2016 : 85-98. Diakses tanggal 21 September 2020.

15. Stuart, G.W. 2016. Prinsip dan Praktik Keperawatan Kesehatan Jiwa Stuart, Edisi Indonesia. Jakarta : Elsevier.

16. Nurmalisyah,F.F. 2018. Pengaruh Psikoedukasi Keluarga Terhadap Beban dan Dukungan Keluarga Dalam Merawat Penderita Skizofrenia di Rumah. Tesis. Progran Studi Magister Keperawatan Fakultas Keperawatan Universitas Airlangga Surabaya. http://repository.unair. ac.id/77888/2/TKP\%2063_18\%20Nur\%20p. pdf. Diakses tanggal 21 September 2020.

17. Widiastuti, A.,Sunarmi.,Purwaningsih.2013. Psikoedukasi Keluarga terhadap Perilaku Keluarga Merawat Pasien Skizofrenia dengan Halusinasi di Wilayah Binaan Rsj Grhasia Desa Selomartani YOGYAKARTA.
Jendela Nursing Jurnal-JNJ Volume 2 No 1/ April 2013. https://www.neliti.com/ publications/243225/psikoedukasi-keluargaterhadap-perilaku-keluarga-merawatpasien-skizofrenia-deng. Diakses tanggal 21 September 2020.

18. Mubin dan Rahayu. 2019. Pengaruh Terapi Psikoedukasi Keluarga Skizofrenia Paranoid Terhadap Kepatuhan Minum Obat Pasien. Jurnal Keperawatan Volume 11 Vol 2 2019: Juni. STIKes Kendal. http://www.journal. stikeskendal.ac.id/index.php/Keperawatan/ article/view/510. Diakses tanggal 21 September 2020.

19. Ahmad, M. Pulungam, Z.A. Hardiyati, H. 2019. Psikoedukasi Meningkatkan Peran Keluarga Dalam Merawat Klien Gangguan Jiwa. Jurnal Keperawatan 11(3):191-198. https://www. researchgate.net/publication/341762738_ Psikoedukasi_meningkatan_peran_keluarga_ dalam_merawat_klien_gangguan_jiwa. diakes tanggal 30 September 2020

20. Sasono dan Rohmi. 2017. Pengaruh Psikoedukasi Keluarga Terhadap Kemampuan Keluarga Dalam Merawat Penderita Skizofrenia. The Indonesian Journal Of Health Science, Vol. 8, No. 2, Juni 2017. http://jurnal.unmuhjember.ac.id/index. php/TIJHS/article/view/864/686. diakses taggal 30 September 2020

21. Qolino,E.Hamid,A.Y. Wardani, I.Y. 2017. Pengaruh Psikoedukasi Keluarga Terhadap Ansietas Dan Depresi Keluarga Yang Mempunyai Anak Dengan Autis Di Sekolah Khusus Autis Harapan Utama Ananda Depok. Jurnal JKFT. Volume 2 N0 2 (2017). http://jurnal.umt.ac.id/index.php/jkft/article/ view/696. diakses taggal 30 September 2020

22. Wulandari,R.A. Soeharto,S. Setyoadi,S. 2016. Pengaruh Terapi Psikoedukasi Keluarga Terhadap Harga Diri Rendah Dan Beban Keluarga Dengan Anak Retardasi Mental. Jurnal IImu Keperawatan. Volume 
4 No 2 (2016). https://jik.ub.ac.id/index. php/jik/article/view/97. diakses taggal 30 September 2020

23. Friedman, Bowden \& Jones (2010). Keperawatan Keluarga; Riset, Teori \& Praktik (Hamid, Sutarna, Subekti, Yulianti \& Herdina, Penerjemah) Jakarta; EGC
24. Purwaningrum,S.W. Rini,T.S. Saurina,N. 2018. Hubungan Tingkat Pengetahuan, Sikap dengan Perilaku Warga dalam Pemenuhan Komponen Rumah Sehat. Jurnal Fakultas Kesehatan Masyarakat Volume 12, Issue 1, March 2018, pp. 53 59 ISSN: 1978 - 0575. Diakses tanggal 29 September 2020. 